\title{
Quality Framework And Indicators For Accreditation Of Teacher Education: International Cases And Suggestions For Nigeria
}

\author{
Steve Nwokeocha \\ Professor and Executive Director \\ Africa Federation of Teaching Regulatory Authorities \\ Abuja, Nigeria \& Centurion, South Africa
}

\begin{abstract}
This paper focused on teacher education and quality assurance issues particularly the quality framework and indicators for accrediting teacher education. It analysed the fact that all parts of the world have not shown equal commitment to the accreditation of teacher education. Similarly, what constitute quality framework and indicators for accrediting teacher education had varied among the countries, higher education agencies and teaching regulatory authorities. For Nigeria, though the professionalization of teaching has advanced, the professional accreditation of teacher education has not kept pace with the advancement. This study was therefore undertaken to take stock of the international best practices in accreditation of teacher education with a view to suggesting quality framework and indicators for the professional accreditation of teacher education in Nigeria.
\end{abstract}

Keywords: Accreditation, teacher education, quality indicators

\section{INTRODUCTION}

If education is the gateway to development, then the teacher holds the key to development because the teacher is first among all the factors that contribute to education quality. Therefore, the teacher ought to be accorded high priority in designing an excellent education system. The primary means to have the right type of teachers for the education system is teacher preparation: the way the teachers are prepared largely account for their quality, performance, status and morale. One of the ways to give teacher preparation the desired attention is quality assurance - which implies bringing every possible elements of teacher preparation into scrutiny and ensuring that they comply with the best standards and practices. Quality assurance therefore is a very complex concept, entailing a large amount of ideas, theories, principles, procedures and actions which a teacher preparation institution must apply and which the teacher regulatory agencies must ascertain and confirm before awarding accreditation status to a teacher education institution.

However, the historical peculiarities in the development of teaching as a profession mean that quality assurance in teacher education has not enjoyed a common understanding and application across the continents. Some jurisdictions had perfected the tenets of professionalization while for others, teaching as a profession is just emerging. In the jurisdictions where teaching is just emerging as a profession, quality assurance in teacher education is equally a relatively new concept.

In many parts of Europe and America, the higher education agencies accredit teacher education as part of the overall accreditation of higher education programmes. But in addition, there are also teacher regulatory authorities statutorily established to have concurrent powers with the higher education agencies in the accreditation of teacher education. Thus, while the 
higher education agencies carry out what may be called general accreditation, the teaching regulatory authorities carry out what is called professional accreditation. The later focuses more on all the relevant canons that make for an excellent teacher education programme. Examples of countries that exercise both general and professional accreditation include the United Kingdom, United States of America and Canada. In analysing quality framework and indicators for accreditation of teacher education, therefore, it is important to take cognisance of the quality frameworks and indicators employed by both the higher education agencies and teaching regulatory authorities.

In other parts of the world where teaching has not been fully professionalised, the higher education agencies have been solely responsible for producing quality frameworks and indicators. Also, these higher education agencies accredit teacher education along with other higher education programmes. Countries in this group are mostly from the developing parts of the world including Nigeria. In the case of Nigeria, though there is the Teachers Registration Council of Nigeria (TRCN), an agency of the Federal Ministry of Education established by law to regulate the teaching profession, it has not yet been involved in the accreditation of teacher education programmes in the universities and colleges of education. However, TRCN has demonstrated the capacity to accredit teacher education by successfully developing and accrediting teacher education programmes such as the Professional Diploma in Education (PDE) and Post-Doctoral Diploma in Education (PDDE) currently run by over fifty colleges of education and a few universities. The PDE and PDDE are new teacher education programmes introduced by TRCN to train graduates who did not read education but who are teaching or interested in teaching. They are not the regular programmes of the universities and colleges of education in Nigeria. TRCN has not for the first time taken part in the accreditation of the regular programmes of these higher institutions. It has the statutory powers to do so, but financial constraints and at times resistance by the higher education agencies which had traditionally been in charge of the universities and colleges of education pose the greatest challenges.

Notwithstanding the inability of TRCN to commence the professional accreditation of teacher education programmes, it is important still to keep abreast of what professional accreditation of teacher education entails and the set of quality framework and indicators used in such accreditation as could be abstracted from the international cases and also some local examples. This is the central purpose of this paper. In the context of the paper, the teaching regulatory authorities refer to statutory agencies set up by law of a province or a country to regulate teaching, which in particular means to set standards that individuals who aspire to practice teaching must attain. The teaching regulatory authorities go by various names, for instance, General Teaching Council for Scotland, TRCN, South African Council for Educators, Teachers Registration Board of South Australia, Ontario College of Teachers, Professional Standards Commission, State of Georgia, and so forth.

The uneven landscape of teacher education accreditation was reflected also in the report by the World Bank Group (2009) on teacher education quality assurance which asserted thus:

The application of accreditation standards to teacher education institutions is not universal. In many countries a large number of teachers are still trained in unaccredited institutions and some school districts hire unlicensed teachers to fill staffing gaps. Countries also vary in terms of priorities and criteria for accreditation of teacher training. These reflect national culture, politics and traditions. Ultimately, however, setting standards and accreditation criteria for teacher education is a political choice, reflecting the model of teacher accountability that prevails in a country. 
Globally, accreditation of teacher education institutions is more common in highly decentralized countries, where the provision of teacher education and training is managed by many different institutions. In such countries, accreditation systems can be an effective tool for policy makers to monitor and improve the quality of education provided to future teachers. (World Bank Group, 2009:2)

Similarly, the report by Eurydice (2006) showed that for most countries, teacher education has no particular or specific regulation for accreditation other than the general rules for accrediting higher education. The research which was initiated by the European Commission on "Quality assurance in teacher education in Europe" reported as follows:

In 24 countries or regions, only general regulations for the evaluation of all higher education apply to the evaluation of teacher education. Apart from the legislative framework for the evaluation or accreditation of higher education, no specific evaluation systems are geared to teacher education. The extent to which these general regulations may take particular components into consideration and examine the quality of specific content in greater detail, largely depends on the documents from which evaluation criteria are derived. In six countries, evaluation of teacher education is governed by both general and specific regulations. In most cases, specific regulations apply to a particular stage of initial teacher education. This may be the professional training phase or a particular part of it in the consecutive model, or the induction phase. (Eurydice, 2006:10)

Basically, therefore, this paper highlights quality indicators used currently for the accreditation of teacher education in selected countries and provinces as well as locally in Nigeria and then suggests a framework of quality indicators for the professional accreditation of teacher education in Nigeria.

\section{METHODOLOGY}

The study was conducted primarily through the review of literature and email correspondences with some of the teaching regulatory authorities across the continents. The author utilised his professional network in the Africa Federation of Teaching Regulatory Authorities (AFTRA) and World Forum of Teaching Regulatory Authorities (www.iftra.org) to secure the data directly from several teaching regulatory authorities across the world. The teaching regulatory authorities were requested to clarify some basic issues regarding their teacher education quality framework and indicators and processes of accreditation and also to submit their latest copy of teacher education accreditation resources. Naturally, they all responded positively and were very helpful. Therefore, the data presented in this paper pertain to authenticated instruments and processes currently in operation in the countries concerned. There were a few exceptions, however, where literature cited was not received from the regulatory authorities. The few exceptions were information extracted from literature on quality framework and indicators written by other scholars who are authorities in quality assurance.

In total, references were made in this paper to several continents covering Australia, New Zealand, India, United Kingdom, Canada, United States, South Africa, Nigeria and others (and of course, the European Union as a bloc). Specific teaching regulatory authorities and other education agencies that participated in the study are:

i. Teachers Registration Board of South Australia

ii. Education Council of New Zealand

iii. Ontario College of Teachers, Canada

iv. General Teaching Council for Scotland, United Kingdom 


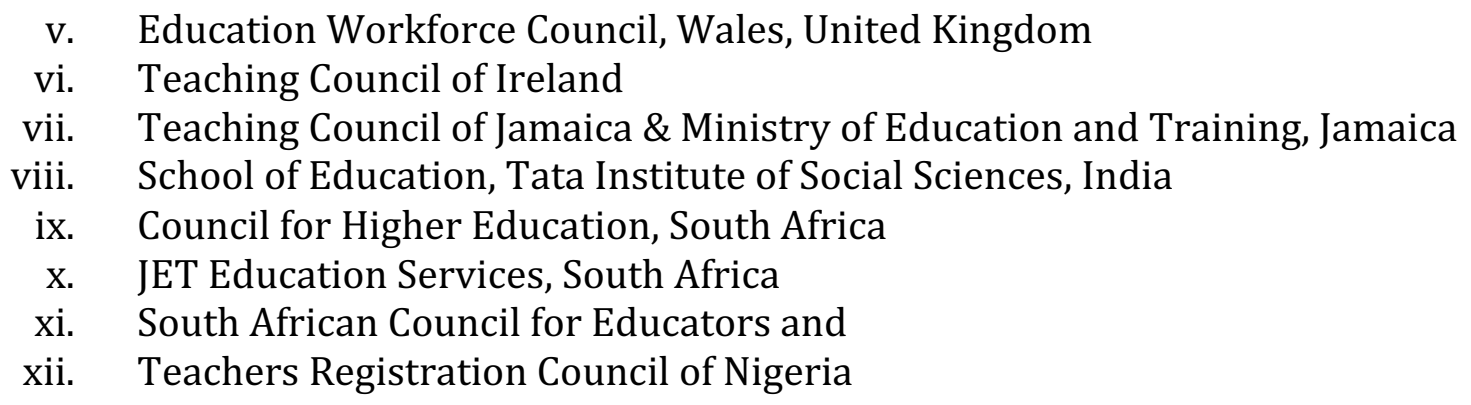

\section{Quality Indicators}

\section{ANALYSIS OF CONCEPTS}

The term quality is nebulous and lacks precise definition. What is quality in one place, time and circumstance may not be quality in another. Thus, some analysts (e.g. National Assessment and Accreditation Council [NAAC] of India \& Commonwealth of Learning [COL], 2007a:11) compared quality to beauty which they said 'is in the eyes of the beholder'. NAAC and COL (2007a) cited the British Standard Institution (1991) which defined quality as "the totality of features and characteristics of a product or service that bear on its ability to satisfy stated or implied needs." They also cited Green and Harvey (1993) who identified five approaches to defining quality such as:

i. In terms of exceptional (exceeding high standards and passing a required standard);

ii. In terms of consistency (exhibited through "zero defects" and "getting right the first time", making quality a culture);

iii. As fitness for purpose (meaning the product or service meets the stated purpose, customer specifications and satisfaction);

iv. As value for money (through efficiency and effectiveness); and as transformative (in terms of qualitative change). (NAAC \& COL, 2007a:11-12)

With these and other conceptualisations of quality cited, the NAAC and COL (2007) concluded that quality is amorphous and contextual, and that the meanings range from 'standard' to 'excellence' and ate rooted in the values of the individual, institution and nation involved. The authors adopted the concept standards and excellence as their benchmark and described them in these terms:

"Standards can be defined in terms of a minimum 'threshold' by which performance is judged" (Aschroft \& Foreman-Peck, 1996, p.21). In this context, quality is assessment in terms of a set of norm-referenced standards (such as the NAAC Criteria) that are built around what is expected at the minimum and beyond. At the other end of the continuum is the consideration of quality as excellence (similar to what Green and Harvey calls exceptional). Excellence is a performance stage of exclusiveness that is distinctive from many others and stand out as a demonstration of 'zero defect' and highest level of satisfaction of the stakeholders. In higher education, our objective is to achieve the 'standard' and move towards 'excellence'.

(NAAC \& COL, 2007a: 13)

Chalmers (2007 \& 2008) equally wrote extensively on 'teaching and learning quality indicators' and acknowledged the difficulty in defining the concept of quality. Nevertheless, Chalmers (2007:35) pointed to the basic agreement that quality stands for 'fitness for purpose'.

Making references to several authors (Borden, \& Bottrill, 1994; Carter, Klein \& Day, 1992; Cave, Hanney \& Kogan, 1991; Richardson, 1994), Chalmers (2008) pointed out four types of performance indicators, namely: input, process, output, and outcome. He further stated that 
these performance indicators can be quantitative and qualitative. Chalmers (2008) citing Cave, Hanney, Henkel and Kogan (1997) also opined that there are three kinds of indicators, namely:

i. Simple indicators are usually expressed in the form of absolute figures and are intended to provide a relatively unbiased description of a situation or process.

ii. Performance indicators differ from simple indicators in that they imply a point of reference; for example, a standard, objective, assessment, or comparator, and are therefore relative rather than absolute in character. Although a simple indicator is the more neutral of the two, it may become a performance indicator if a value judgment is involved.

iii. General indicators are commonly externally driven and are not indicators in the strict sense; they are frequently opinions, survey findings or general statistics.

(Chalmers, 2008:4)

He stated that quality indicators are not 'facts' but goals, values and aspirations of a people within contexts and involves judgement. Thus, the ways of utilising them depend on the model of assessment adopted. Conclusively and citing the following sources (Bruwer, 1998; Burke \& Minassians, 2002; Burke, Minassians \& Yang, 2002; DEST, 2002; Romainville, 1999; Rowe \& Lievesley, 2002) he gave the following as the basic definition of teaching quality indicators:

Performance indicators are defined as measures which give information and statistics context; permitting comparisons between fields, over time and with commonly accepted standards. They provide information about the degree to which teaching and learning quality objectives are being met within the higher education sector and institutions. (Chalmers, 2008:4)

In a nutshell, this paper subscribes to the definition of quality as used by NAAC and COL (2007a) and Chalmers (2007 \& 2008) which held that quality means fitness for purpose and performance with regards to set standards, criteria or minimum threshold. In the case of teacher education, the standards are set by the higher education agencies and teaching regulatory authorities. Similarly, quality indicators in respect of a teacher education programme refer to measures (artefacts, statistics, records and knowledgeable opinions) that show the degree to which a teacher education programme meets the standards, criteria or threshold set by the relevant authorities.

\section{Quality Framework}

Quality framework in this paper refers to the mapping of all dimensions and indicators of quality in teacher education. Since the individual indicators are too many and cannot be listed exhaustively, scholars attempt to group them for analytical purposes. The framework is thus the grouping of all possible criteria for accreditation of teacher education in the various countries and jurisdictions. Importantly, this study took cognizance of the dimensions of quality such as input, process, output and outcome of teacher education as proposed by Chalmers $(2007,2008)$, an authority on quality assurance. These four dimensions interact in a complex way with other elements in any education programme. For instance, in any education programme, according to Chalmers, there are four categories of elements such as:
i. Assessment
ii. Engagement and learning community
iii. Diversity and
iv. Institutional climate and systems

Further again, in any educational programme, according to Chalmers, there at least four levels of activities such as:

i. Institutional level

ii. Faculty level 


\section{iii. Department/programme level and \\ iv. Teacher/Individual level}

The four dimensions of quality (input, process, output and outcome) interact with the four categories of elements (assessment, engagement, diversity and institutional climate and systems) and four levels (institutional, faculty, department/programme and teacher/individual levels), thereby producing a complex set of quality indicators. This complex set of indicators is referred to as the quality framework. In other words, the quality framework is all possible indicators produced by a complex mix of all dimensions, elements and levels in any teacher education programme.

Also, an important publication of the UNESCO-International Institute for Capacity Building in Africa (IICBA), titled Fundamentals of Teacher Education: Quality Assurance of Teacher Education in Africa, authored by Sanyal (2013) explored the concept of quality assurance framework for teacher education in Africa. Like Chalmers (2008), Sanyal opined that the basic framework for assessing the quality of teacher education must include inputs, outcomes, learner characteristics, teaching-learning materials, physical infrastructure and facilities, human resources, school governance and context.

\section{Accreditation}

Accreditation stands for such other terms as authorisation, recognition, endorsement or approval and the accreditation process refers to procedures, steps, phases or stages leading to the endorsement or approval of any programme, which is teacher education in this case. For instance, Eurydice (2006:7) defined accreditation as "a process by which an institution or a programme is judged by the relevant legislative and professional authorities as having met predetermined standards in order to provide (teacher) education or training and to award the corresponding qualifications." It further defined an associated term, evaluation, as "a general process of systematic and critical analysis leading to judgments and/or recommendations for improvement regarding the quality of a (teacher) education institution or programme." Similarly, the General Teaching Council for Scotland, GTCS (2018:2) defined accreditation as "the process of ascertaining the professional acceptability of a programme of Initial Teacher Education (ITE) leading to a teaching qualification." Based on these definitions, accreditation may be both a process and outcome. It has to do with the evaluation and endorsement of the quality of a programme. It entails careful observation, documentation, analysis, inferences, recommendations and decision-making.

\section{PROFESSIONAL STANDARDS AT CENTRE OF ACCREDITATION}

It has been stated earlier that quality basically has to do with meeting standards and being fit for purpose. In respect of teacher education, the professional standards for teachers are the key references. Part of why teaching 'failed' in many developing countries was because professional standards were non-existent or not the guiding principles of much of the policies, programmes, and actions that had to do with teacher education and practice. It was a case of putting the cart before the horse because stakeholders first dabbled into all manners of teacher education, assessment, rewards, policies and implementation before turning around to look for what constitutes teaching standards. People became teachers before asking about what constitutes a professional teacher or before talking about teacher professionalization, registration and licensure. Conversely, the advanced nations understood that professional standards had to be put in place first to serve as the pivot of teacher preparation, performance assessment, teacher reward, career progression and other teaching policies and practices. In such climes, teachers first qualify and get registered and licensed before they could be hired to teach. 
The point here is that the international community is in agreement that professional standards must be at the heart of teacher preparation, career path, performance assessment, rewards and overall motivation. Professional standards are defined as statements of what a teacher must know and do and how at teacher must conduct himself or herself in professional contexts. Put differently, they are statements of competences of knowledge, skills and conduct expected of teachers. Ingvarson (2002), a scholar with extensive research on teaching standards had this to say about professional standards. He stated that teaching standards are:

statements about what is valued. As measures, standards will not only describe what teachers need to know and be able to do to put these values into practice; they will describe how attainment of that knowledge will be assessed, and what counts as meeting the standard. A standard, in the latter sense, is the level of performance on the criterion being assessed that is considered satisfactory in terms of the purpose of the evaluation. (Ingvarson, 2002:3)

The fact professional standards should be at the heart of teacher issues was equally highlighted by Gallie and Keevy (2014).

There is a huge difference between professional standards and individual standards associated with persons, institutions and subsectors of the education system. Individual standards are at best limited and not a product of system-wide consensus whereas professional standards are system-wide and represent the consensus of all critical stakeholders. For this reason, the professional standards are superior to all other standards set by individuals, institutions and subsectors. The popularity and system-wide acceptability of professional standards therefore make them powerful as tools for regulating teacher education in all ramifications (Nwokeocha, 2017:13-15).

Accordingly, it is a common position of the continental and global education authorities that teacher professional standards should be the benchmark for the regulation of the teaching profession. These authorities include the International Forum of Teaching Regulatory Authorities (IFTRA), Africa Federation of Teaching Regulatory Authorities (AFTRA), United Nations International Task Force on Teachers for Education (ITFTE) 2030, African Union Commission, Education International, and a host of others. The ITFTE had its $10^{\text {th }}$ Annual World Dialogue Forum in Lome, Togo, in September 2017 and the theme was "Teaching: A Profession." The choice of the theme was to underscore the global dedication to the professionalisation of teaching. Part of the outcome of the Forum was a declaration that professional standards should now be given priority attention and should underpin other relevant teacher issues (International Task Force on Teachers for Education 2030, 2017).

The essence of the foregoing is to stress the critical importance of professional standards for teachers, particularly the accreditation of teacher education programmes. Ultimately, quality assurance in teacher education is primarily an exercise to meet the aims and aspirations of the professional standards. This fact is also very obvious in most of the accreditation frameworks and processes reviewed in this report. From Australia to New Zealand, United Kingdom, Canada and United States of America, the benchmarks for accrediting teacher education require the Teacher Education Institutions (TEI) to demonstrate that their programmes can meet or have fulfilled the professional standards. The quality framework and indicators for the accreditation of teacher education suggested for Nigeria in the latter part of this paper are equally founded on this paradigm. 


\section{Australia}

\section{COUNTRY CASES OF QUALITY INDICATORS}

Australia has one of the best regulated teaching professions in the world with thoroughly developed and sophisticated national benchmarks for managing the various aspects of the profession. Though Australia has provinces that are autonomous in the management of their education systems, the Australian Provincial Ministers of Education commit to common national benchmarks for the regulation of the teaching profession (Australian Institute for Teaching and School Leadership, AITSL, 2011). This body of Ministers is known as the Ministerial Council for Education, Early Childhood Development and Youth Affairs (MCEECDYA). Consequently, Australia has common national benchmarks for professional teaching standards as well as teacher education accreditation standards and procedures. Each province then develops descriptors to suit their local contexts. The review of the Australian accreditation system and professional standards in this study therefore focused on the national benchmarks.

The national benchmark for quality assurance in teacher education is issued by the Australian Institute for Teaching and School Leadership, AITSL (2015a, 2015b) on behalf of MCEECDYA, and the benchmark is titled National Accreditation Standards and Procedures. However, there are also other national benchmarks applicable to all higher education programmes in Australia which teacher education programmes must comply with. These are the Education Services for Overseas Students Act 2000 (Australian Government, 2000) and Higher Education Standards of the Tertiary Education Quality and Standards Agency Act 2011 (Australian Government, 2011). The Act of 2000 stipulates the rights and privileges of foreign students in Australian universities and the Act of 2011 provides the general quality guidelines for all tertiary education programmes in Australia.

The narratives below are basically the provisions of the Australian National Professional Standards for Teachers (AITSL, 2011), Accreditation Standards and Procedures (AITSL, 2015a) and related policies and literature. The teaching regulatory authorities of the various provinces of Australia are the primary implementers of the professional standards and the laws of the provinces vests them with powers to accredit teacher education, and to register and license teachers.

The Australian national professional standards (AITSL, 2011):

The table below shows the structure of the Australian national professional standards.

Table 1: The structure of the Australian national professional standards (Illustrated)

\begin{tabular}{|l|l|l|}
\hline $\begin{array}{l}\text { Domains of } \\
\text { teaching }\end{array}$ & Standards & $\begin{array}{l}\text { Focus areas and standard } \\
\text { descriptors }\end{array}$ \\
\hline $\begin{array}{l}\text { Professional } \\
\text { Knowledge }\end{array}$ & 1. Know students and how they learn & $\begin{array}{l}\text { This column contains } \\
\text { elaborations and descriptors } \\
\text { according to provinces. }\end{array}$ \\
\cline { 2 - 3 } $\begin{array}{l}\text { Professional } \\
\text { Practice }\end{array}$ & $\begin{array}{l}\text { 3. Plan for and implement effective teaching } \\
\text { and learning }\end{array}$ & Ditto \\
\cline { 2 - 3 } & $\begin{array}{l}\text { 4. Create and maintain supportive and safe } \\
\text { learning environments }\end{array}$ & Ditto \\
\cline { 2 - 3 } & $\begin{array}{l}\text { 5. Assess, provide feedback and report on } \\
\text { student learning }\end{array}$ & Ditto \\
\hline $\begin{array}{l}\text { Professional } \\
\text { Engagement }\end{array}$ & $\begin{array}{l}\text { 7. Engage in professional learning } \\
\text { parents/carers and the community }\end{array}$ & Ditto \\
\hline
\end{tabular}

Source: Illustrated by the author with information from AITSL (2011:3) 
There are three domains as follows: (i) professional knowledge with two standards; (ii) professional practice with three standards; and (iii) professional engagement with two standards making a total of seven standards. Each of the standards has sub-standards with descriptors. Part of the novelty of the Australian model is that it also institutionalised career path for teachers. Thus, the standards recognised four career stages called Graduate, Proficient, Highly Accomplished and Lead. Each of these career stages has its own standards and substandards clearly defined in the complex matrix of the Australian standards. Indeed, Australia is among the few countries in the world where teacher career path has been documented in the teaching standards but operationalized in reality. Every teacher education programme in Australia is required, as part of the teacher accreditation process to document plans for attaining the above standards (in the case of a new teacher education programme) or provide evidences that the standards are already attained by graduates (in the case of an old or existing teacher education programme) and the impact the graduates of the programme can or had made in the education system.

\section{The Australian national accreditation standards and procedures (AITSL, 2015b)}

The Australian accreditation standards and procedures are products of AITSL's consultation with critical stakeholders in the teaching profession in particular and education in general. According to the AITSL, the benchmarks "draw on the expertise and vision of teacher educators, employers of teachers, those in the teaching profession, in schools and early childhood settings and the broader education community, and embody the ongoing sectorwide commitment to driving improvement in teacher education" AITSL (2015a:2).

The Australian national accreditation document has three key parts, namely:

i. National programme standards (defines what constitutes quality indicators for initial teacher education, ITE)

ii. Graduate teacher standards (provides that the primary purpose of the ITE is to meet the Australian National Professional Standards for Teachers) and

iii. National accreditation process (provides for the steps, duration, appeals, panels, reporting, framework and continuous improvement)

These are briefly discussed in turn.

Basically, the national programme standards require two types of evidences:

i. Evidence of pre-service teacher programme performance, which is internal to the programme and measures the impact of the programme on the trainees - measures that prove that the graduates had acquired competences in line with the Australian Professional Standards for Teachers, and that the graduates are impacting positively on learning.

ii. Evidence of graduate outcomes, which is external and assesses the achievements of graduates after completion of the programme, particularly to show that the teachers are actually effective classroom teachers.

The following are the national programme standards that guide the accreditation of teacher education:

- Standard 1: Program outcomes

- Standard 2: Program development, design and delivery

- Standard 3: Program entry

- Standard 4: Program structure and content

- Standard 5: Professional experience

- Standard 6: Program evaluation, reporting and improvement. 
As stated earlier, the primary purpose of the National Programme Standards is to satisfy the requirements of the National Professional Standards for Teachers. Therefore, the Accreditation Standards and Procedures clearly state that the National Professional Standards is at the heart of the National Programme Standards (AITSL 2015a, 2015b, 2015c, 2016 \& 2018).

Fig. 1: The Australian teacher education accreditation process with the National Professional Standards for Teachers as pivot.

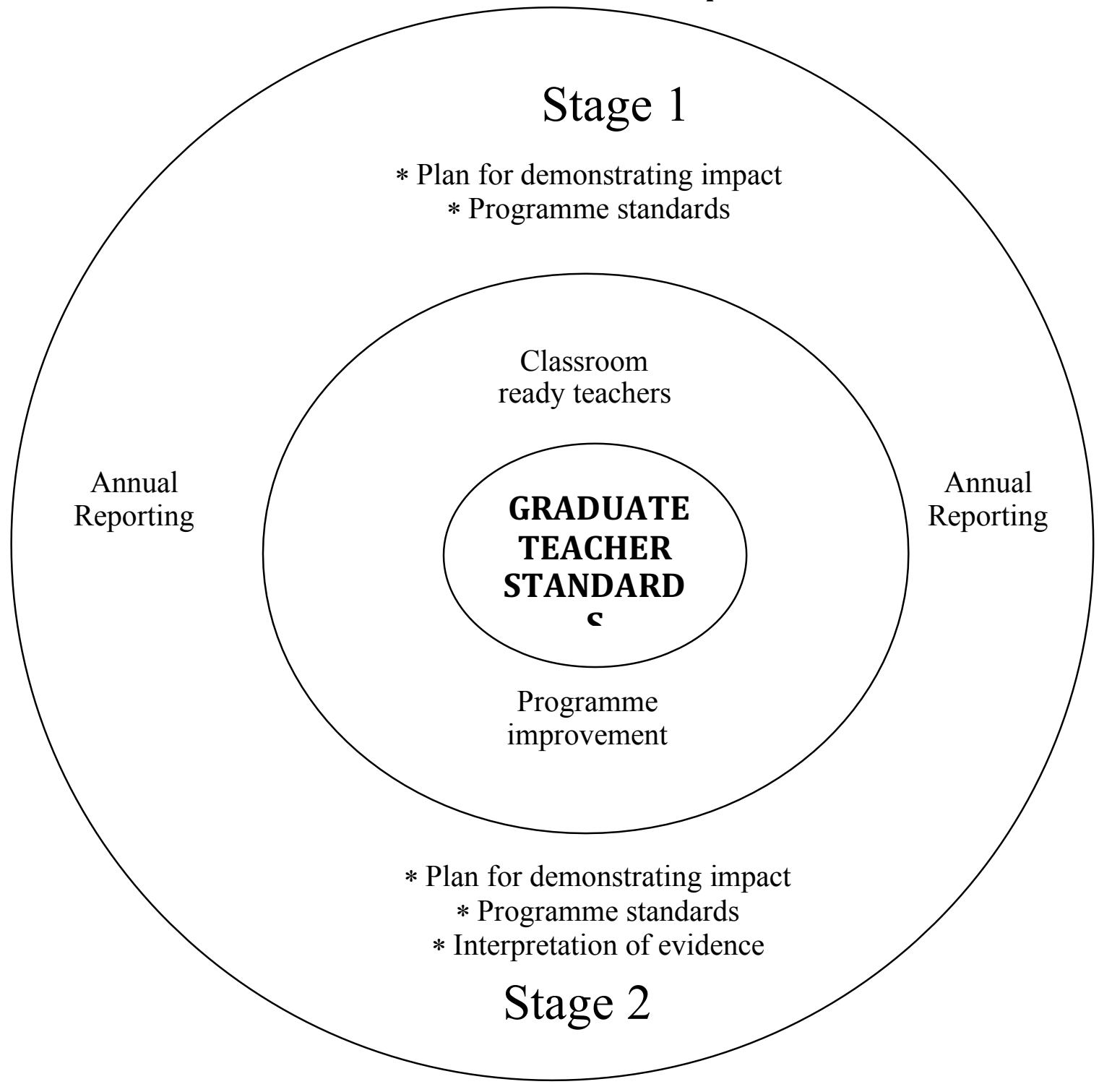

Source: AITSL (2015a:6)

It is important to conclude the Australia case by recalling the assertions of the Australian Teacher Education Ministerial Advisory Group (2014) in its publication titled "Best practice teacher education programs and Australia's own programs." The Group asserted that professional standards for teachers and effective accreditation are the best guarantees of quality in the teacher education programmes.

\section{New Zealand}

New Zealand, a neighbouring country to Australia shares a strong relationship with Australia in the regulation of its teaching profession to promote teacher mobility across their political boundaries. Unlike Australia, however, education in New Zealand is managed nationally in many respects including the regulation of teaching. The Education Council of New Zealand is 
responsible for this. As in Australia, the professional standards for teachers form the basis for the accreditation of teacher education in New Zealand. This fact is briefly illustrated here.

The Standards for the Teaching Profession in New Zealand issued by the Education Council (2018), titled "Code of professional responsibility and standards for the teaching profession" has six standards as follows:
i. $\quad$ Partnership
ii. Professional learning
iii. Professional relationships
iv. Learning-focused culture
v. Design for learning
vi. Teaching

The New Zealand professional standards for teachers are stated very briefly - it is among the 'shortest' professional standards in the world, unlike Australia that has one of the most complex and voluminous standards. Also, the New Zealand standards did not provide for career path for teachers like the Australian case. The Education Council (2018) opined that it deliberatively couched the standards at "high level" (few general statements) so as to allow individuals and institutions to elaborate and apply them to their contexts.

Using the professional standards for teachers as guide, the Education Council (2016) gave the following as areas of concern for the accreditation of teacher education programmes, among others:

i. A conceptual framework - Philosophical base of the programme which includes principles, beliefs and values about teacher education, teaching, and learning.

ii. Research - How far the programme is informed and led by research.

iii. The Graduating Teacher Standards - Demonstrating how the professional standards will be attained.

iv. Academic entry requirements for students

v. Literacy (English language competency)

vi. Numeracy

vii. Information technology - ICT competency

viii. Te reo Māori competency

ix. Admission processes

x. Practicum length

xi. Programme delivery

xii. Police vetting of candidates

xiii. 'Good Character' and 'Fit to be a Teacher'

xiv. Recognition of prior learning

xv. Maximum time for completion.

The application for accreditation by a teacher education institution is expected to deal with these issues in depth, and provide evidences to convince the Education Council that the programme is fit to run. There are also accreditation processes stipulated which are almost of a generic nature like the ones in Australia. Typically, accreditation is for three to four years in the first instance and the accredited programme is monitored annually by an external assessor who sends report and the institution also sends annual report. However, once a programme survives this duration, it then gains accreditation for up to six years before another review. 


\section{United Kingdom}

The United Kingdom has provinces that independently manage their education systems and regulate their teaching professions. The oldest teaching council in the world is in the United Kingdom and that is the General Teaching Council for Scotland (GTCS) established by an Act of 1965. The GTCS has also proved to be one of the most stable teaching councils in the world, with teaching councils even in the United Kingdom rising and falling - for instance, the General Teaching Council for England was established in 2000 and later scrapped in 2012 while the General Teaching Council for Wales had metamorphosed into the Education Workforce Council, though still the regulator of the teaching profession in Wales. Furthermore, Scotland is one of the jurisdictions where entry requirements into the teaching profession has been rising to a point that many teachers already have a Master degree and the GTCS is considering making Master degree the minimum entry into the teaching profession in the near future.

Against this background, it was important to review the quality benchmarks of Scotland for teacher education. Again, as done in the previous cases, the review looked at the professional standards for teachers and then the accreditation framework and process. It is interesting to note that the Accreditation Framework for Scotland was approved on June 13, 2018 and sent immediately to this author for use in this study; it is therefore the freshest of all the accreditation references in this study.

The GTCS (2012) "Code of professionalism and conduct" contains the professional standards for the province and they are in five parts as follows:

- Part 1: Professionalism and maintaining trust in the profession

- Part 2: Professional responsibilities towards pupils

- Part 3: Professional competence

- Part 4: Professionalism towards colleagues, parents and carers

- Part 5: Equality and diversity

As in the case of the other countries, these five parts of the code of professionalism and conduct are also broken down into sub-standards according to the more detailed concerns of the regulatory authorities.

The accreditation document released by the GTCS (2018) gave the list below, among others, as the framework for evaluating teacher education programmes in Scotland:

i. Statutory requirements - Evidences that the programme meets statutory requirements; internal quality assurance mechanisms to ensure quality programme content, design, relevance.

ii. Staffing and levels of effective delivery - Expertise of staff and how they can support the programme.

iii. Programme design - Stated programme aims and outcomes, how the programme promotes equality and diversity and checks discrimination, and how it builds learner knowledge and skills.

iv. Recruitment and selection of students - How the programme is marketed, selection criteria, interview process, panel composition, promotion of diversity among students, monitoring and evaluation of admission.

v. Support for student teachers - Availability of support to students during studies and professional placements.

vi. Content of the programme - Theoretical foundations of the programme; strategies for developing the students' literacy, numeracy, digital literacy, well-being, curriculum, and inter-disciplinary learning. 
vii. Professional values - Capacity of the programme to promote teacher professional values.

viii. Delivery of programme - Rationale for programme delivery models, academic calendar, and opportunities for students' collegiate and collaborative learning.

ix. Assessment - Assessment strategies, their diversity, rationale and effectiveness; support for weak students and process for appeals, resits and extension.

x. Partnerships - Partnerships for professional placements of students.

An earlier publication of the GTCS (2016) on accreditation guidelines which is still in operation (the recent GTCS document dealt specifically with the accreditation framework) provides information regarding other requirements and procedures for accreditation. A few of the points could be mentioned here: The duration of accreditation is six years; institutions desiring accreditation first discusses informally with the GTCS to express their interest.

\section{European Union}

European Commission on Education and Culture $(2010,2018)$ has a variety of documents that state the common principles for the teaching profession in Europe as well as quality assurance framework for teacher education programmes. The document titled "Common European Principles for Teacher Competences and Qualifications" (European Commission, Education and Culture, 2010) listed the principles as:

i. A well-qualified profession: This requires teachers to possess extensive knowledge, skills and excellent professional relations.

ii. A profession placed within the context of lifelong learning: This principle requires teachers to engage in continuous professional development programmes and lifelong learning.

iii. Mobile profession: This principle requires teachers to have the capacity to work and fit into the education systems across Europe. This implies that teachers must be exposed to professional learning and standards in the European continent.

iv. Profession based on partnerships: This principle emphasizes the collaboration of the various stakeholders in the teacher education and professional practice.

In a paper for the European Commission, Education and Training 2020 Thematic Working Group, Caena (2011) extensively reviewed literature on teachers' core competencies in Europe and asserted that "usually, the competence areas include subject and pedagogical knowledge, assessment skills, teamwork abilities, the social and interpersonal skills necessary for teaching, awareness of diversity issues, research skills, as well as organisational and leadership skills; they all make references to the eight European key competences for lifelong learning." (p.8). The European Commission (2018) "Key Competences for LifeLong Learning" include the following: Communication in the mother tongue; Communication in foreign languages; Mathematical competence and basic competences in science and technology; and Digital competence. Others are Learning to learn; Social and civic competences; Sense of initiative and entrepreneurship; and Cultural awareness and expression.

Expectedly, the framework for accreditation of teacher education programmes put the above principles and core competences at the centre. There is however no single document that gives details of all the requirement for accreditation. Rather the requirements could be inferred from a number of authorities and informed sources that include Caena (2014), Commission des titres d'ingénieur (CTI) (2017) and Eurydice (2006), among others. Caena's (2014) reiterates an earlier point made in this paper that accreditation of teacher education takes place in Europe as in other continents unevenly: 
In most countries, evaluation regulations for higher education apply to initial Teacher Education (ITE). Evaluation is compulsory or recommended in most countries (Eurydice 2006, 2013). There can be specific criteria for ITE, sometimes about a specific stage or aspect (evaluation of school practice provision in Ireland; final 'onthe-job' phase in Germany). Regulations often entail more than one procedure, with external and internal evaluation. Given the complexity of ITE, there might be separate evaluations for different components, organization aspects, settings or stages.

External evaluation for ITE programmes is often carried out by independent quality assurance agencies for tertiary education. In four countries, responsibility lies only with top-level education authorities (the ministry) that in turn can appoint external evaluation teams. In some national contexts the Inspectorate for school education is involved, or the Teaching Council. The external evaluation team can thus include peers, evaluation experts, inspectors and foreign experts; in some countries it is compulsory or recommended to include students. (Caena, 2014:8)

Caena (2014:8) further lists the scope of accreditation to include "curriculum content and balance, instructional strategies, assessment, management of school practice and partnerships, human resources management (qualifications and experiences of teacher educators), and infrastructure. Half of the countries also take into account students' attitudes and opinions."

Eurydice (2006) on its publication on "Quality assurance in teacher education in Europe" equally discussed the scope of accreditation of teacher education in Europe. The scope includes curriculum content, teaching methods, assessment practices, balance between professional and general training, teaching practice, and partnership with stakeholders. Others are human resources management, teacher-student ratio, students' performance, students' opinions and motivation, and general infrastructure. In terms of accreditation procedures, individual European countries conduct this according to national regulations.

\section{Canada}

Unlike Australia, Canada does not have a national framework for regulation of teaching and this includes accreditation of teacher education. Each province is autonomous and has its own laws that guide its education system. The Ontario Province has one of the most popular teaching regulatory authorities in the world, known as the Ontario College of Teachers (OCT) and the province is used to illustrate the case of Canada in this study. The OCT as a world leading teaching council has put in place what is expected in the regulation of teaching in the province. Unlike other provinces and countries where teaching councils do not accredit teacher education, the OCT has the statutory responsibility for accrediting teacher education in Ontario and this includes pre-service and in-service teacher education: The Ontario College of Teachers Act 1996 (Ontario, 1996) provided for the accreditation of teacher education and the details are in the Ontario College of Teachers (1996) "Regulation 347/02: Accreditation of teacher education programmes," which is a subsidiary legislation of the 1996 Act.

In addition to pre-service teacher education, teachers are required to obtain school leadership certificate before they can be appointed to leadership and management positions as school principals. There are also other forms of additional qualifications specified by the OCT which teachers may obtain as a form of extending their professional knowledge (2016). The OCT (2016) states as follows:

The regulated system of Additional Basic Qualifications (ABQs) and Additional Qualifications (AQs) is one form of professional learning. ABQS/AQs are recognized in legislation, accredited by the College, offered by providers approved by the College 
and, when successfully completed, recorded on the member's Certificate of Qualification and Registration. (OCT, 2016:3)

The OCT's professional learning framework and professional and ethical standards are integral parts of teacher professionalism in the province (Ontario College of Teachers, 2017a). A teacher education programme in Ontario must comply with the professional learning framework (Ontario College of Teachers, 2017a) and meet the professional and ethical standards. The ethical standards for the teaching profession are: Care, Trust, Respect and Integrity (Ontario College of Teachers, 2018). The professional standards for the teaching profession are:

i. Commitment to students and student learning

ii. Professional knowledge

iii. Professional practice

iv. Leadership in learning communities and

v. Ongoing professional learning

(Ontario College of Teachers, 2018)

The OCT (2017b) produced a document tilted Accreditation Resource Guide that lists the key provisions of the Regulation 347/02 Accreditation of teacher education programmes and their explanations. Key areas of concern for the accreditation are curriculum of teacher education, use of education and research data, use of educational technology, application of theories of learning, classroom management and organisation, assessment and evaluation, language proficiency, and teaching subjects. Others are students with special needs, education law, professional relationships, knowledge of Ontario context, indigenous cultures and languages, sch+ool safety, and practicum, among others (Ontario College of Teachers, 2017b).

OCT (2015:2) introduced reforms in the teacher education in Ontario with the following changes:

i. four semesters (up from two)

ii. more time for practice teaching (80 days minimum, up from 40)

iii. greater focus on students' mental health and well-being, parent engagement and communication, and special education among other core elements

iv. greater attention to diversity in Ontario classrooms and knowledge of the Ontario context a greater understanding about how to teach with technology.

This implied longer duration for teacher education than it used to be. The reform was informed by research and stakeholder opinion about the need to strengthen teacher education and allow more time for student teachers to be grounded and "to give future teachers more practical experience and greater exposure to teaching methods that will help teachers support diverse student needs" (OCT, 2015:2).

\section{United States of America}

The United States of America (USA) is a country with a decentralised education system and the accreditation education is mostly done by the various professional networks and independent professional accrediting organisations (Eaton, 2016). A number of these are in the teacher education sector and have perfected the art of accrediting teacher education at the university level (Sywelem, 2014). Three among these popular organisations that accredit teacher education in the United States are the Council for the Accreditation of Educator Preparation, CAEP (2018); National Council for Accreditation of Teacher Education (NCATE, 2008) and Teacher Education Accreditation Council (TEAC, 2012). Their frameworks for accreditation are built around the knowledge, skills and professional relationships expected of American 
teachers. Here, the brief review focuses on their areas of concern for the accreditation of teacher education. The areas of concern of the different accrediting bodies are outlined in the tables that follow.

Table 2: The five CAEP standards

\begin{tabular}{|l|l|}
\hline SN & CAEP Standards \\
\hline 1 & Content and pedagogical knowledge \\
\hline 2 & Clinical partnerships and practice \\
\hline 3 & Candidate quality, recruitment and selectivity \\
\hline 4 & $\begin{array}{l}\text { The provider demonstrates the impact of its completers on P-12 student learning and } \\
\text { development, classroom instruction, and schools, and the satisfaction of its completers } \\
\text { with the relevance and effectiveness of their preparation. }\end{array}$ \\
\hline 5 & $\begin{array}{l}\text { Quality assurance system comprising of valid data from different sources and } \\
\text { measures to serve as evidence that the programme meets the professional standards. }\end{array}$ \\
\hline
\end{tabular}

Source: Extracts from CAEP $(2016,2018)$

Table 3: The six NCATE standards

\begin{tabular}{|l|l|}
\hline SN & NCATE Standards \\
\hline 1 & Candidate knowledge, skills, and professional dispositions \\
\hline 2 & Assessment system and evaluation \\
\hline 3 & Field experiences and clinical practice \\
\hline 4 & Diversity \\
\hline 5 & Faculty qualifications, performance, and development \\
\hline 6 & Governance and resources \\
\hline
\end{tabular}

Sources: Extracts from NCATE (2008:13)

Table 4: The TEAC's three Quality Principles

\begin{tabular}{|l|l|l|}
\hline SN & TEAC'S Quality Principles & Descriptors \\
\hline 1 & Evidence of candidate learning: & 1.1 Subject matter knowledge \\
& & 1.2 Pedagogical knowledge \\
& & 1.3 Caring and effective teaching skill \\
& & 1.4 Cross-cutting themes, etc. \\
\hline 2 & Evidence of faculty learning and & 2.1 Rationale for the assessments \\
& inquiry: & 2.2 Program decisions and planning based \\
\hline 3 & Evidence of institutional & 3.1 Commitment (program parity with the \\
& commitment and program & institution) \\
& capacity for quality & 3.2 Sufficient capacity for quality \\
& & 3.3. State standards, etc. \\
\hline
\end{tabular}

Source: Extracts from TEAC (2012:28-31)

The areas of concern listed by Eaton (2016) who also reviewed accreditation in the USA agrees with the contents of the tables above. According to Eaton, the general areas of concern for accreditation in the United States include: student achievement, curricula, faculty, facilities and equipment, fiscal and administrative capacity, student support services, recruitment and admission practices, programme objectives and duration, treatment of students' complaints and compliance with education laws.

\section{South Africa}

Teacher education in South Africa is accredited by the Council on Higher Education (CHE) which is the accrediting agency for higher education in the country. The country's teacher regulatory authority, South African Council for Educators (SACE) has no provision in its law to accredit teacher education. Therefore, teacher education in South Africa depends on the 
generic framework and quality indicators applied to other higher education programmes. According to the Framework for Programme Accreditation (CHE, 2004a), Criteria for Programme Accreditation (CHE, 2004b) and Accreditation Revisited (CHE, 2014) accreditation of higher education programmes in South Africa is based on nineteen criteria such as programme design, student admission processes, staffing, teaching and learning strategy, student assessment policies and procedures, infrastructure and library resources, programme administration and post graduate polices and regulations. Other criteria are programme coordination, academic development, teacher-student interaction, mentoring, and delivery of post graduate programmes, among others.

\section{Commonwealth of Learning}

The Commonwealth of Learning and National Assessment and Accreditation Council (2007a; 2007b) did a lot of work on the quality framework and indicators for the accreditation of teacher education. They came to a conclusion that there are six key areas to consider and based on these six key areas there are twenty five (25) quality aspects and seventy five quality indicators. These are summarised in the table below

Table 5: Distribution of quality aspects \& quality indicators within the key areas

\begin{tabular}{|c|c|c|}
\hline Key Area (KA) & Quality Aspect (QA) & Quality Indicator (QI) \\
\hline \multirow{4}{*}{$\begin{array}{l}\text { I. } \\
\text { Curriculum } \\
\text { Design and } \\
\text { Planning }\end{array}$} & 1. Institutional Vision & QI 1 \\
\hline & $\begin{array}{l}\text { 2. Process of Curriculum } \\
\text { Design }\end{array}$ & QI 2, QI 3 \& QI 4 \\
\hline & 3. Curriculum Content QI 5, & QI 6, QI 7, QI 8 \& QI 9 \\
\hline & 4. Curriculum Revision & QI 10 \& QI 11 \\
\hline \multirow{5}{*}{$\begin{array}{l}\text { II. } \\
\text { Curriculum } \\
\text { Transaction } \\
\text { and } \\
\text { Evaluation }\end{array}$} & 5. Induction / Orientation & QI 12 \& QI 13 \\
\hline & 6. Transaction of Theory & QI 14, QI 15, QI 16 \& QI 17 \\
\hline & $\begin{array}{l}\text { 7. Transaction of Practical } \\
\text { Experiences }\end{array}$ & QI 18, QI 19, QI 20 \& QI 21 \\
\hline & $\begin{array}{l}\text { 8. Assessment and } \\
\text { Evaluation }\end{array}$ & QI 22, QI 23, QI 24 \& QI 25 \\
\hline & 9. Teacher and Teaching & QI 26, QI $27 \&$ QI 28 \\
\hline \multirow{2}{*}{$\begin{array}{l}\text { III. } \\
\text { Research, } \\
\text { Development } \\
\text { and Extension }\end{array}$} & $\begin{array}{l}\text { 10. Research and } \\
\text { Development }\end{array}$ & QI 29, QI 30, QI 31 \& QI 32 \\
\hline & 11. Community Engagement & QI 33 \& QI 34 \\
\hline \multirow{3}{*}{$\begin{array}{l}\text { IV. } \\
\text { Infrastructure } \\
\text { and Learning } \\
\text { Resources }\end{array}$} & 12. Physical Infrastructure & QI 35 \& QI 36 \\
\hline & 13. Instructional Infrastructure & QI 37 \\
\hline & 14. Human Resources & QI 38, QI 39 \& QI 40 \\
\hline \multirow{6}{*}{$\begin{array}{l}\text { V. } \\
\text { Student Support } \\
\text { and Progression }\end{array}$} & 15. System Efficiency & QI 41, QI 42 \& QI 43 \\
\hline & 16. Feedback Mechanism & QI 44, QI 45 \& QI 46 \\
\hline & $\begin{array}{l}\text { 17. Diagnosis and Remedial } \\
\text { Programme }\end{array}$ & QI 47, QI 48 \& QI 49 \\
\hline & $\begin{array}{l}\text { 18. Guidance and Counseling } \\
\text { Service }\end{array}$ & QI 50, QI 51 \& QI 52 \\
\hline & 19. Admission Procedure & QI 53 \& QI 54 \\
\hline & $\begin{array}{l}\text { 20. Social, Cultural and } \\
\text { Leisure Activities }\end{array}$ & QI 55 \& QI 56 \\
\hline \multirow{5}{*}{$\begin{array}{l}\text { VI. } \\
\text { Organisation and } \\
\text { Management }\end{array}$} & $\begin{array}{l}\text { 21. Internal Coordination } \\
\text { and Management }\end{array}$ & QI 57, QI 58, QI 59, QI 60 \& QI 61 \\
\hline & 22. Academic Calendar & QI 62 \& QI 63 \\
\hline & 23. Faculty Recruitment & QI 64, QI 65 \& QI 66 \\
\hline & 24. Financial Governance & QI 67, QI 68, QI 69, QI 70 \& QI 71 \\
\hline & $\begin{array}{l}\text { 25. Academic Quality and } \\
\text { Management }\end{array}$ & QI 72, QI 73, QI 74 \& QI 75 \\
\hline
\end{tabular}

Source: National Assessment and Accreditation Council \& Commonwealth of Learning (2007a:11-12). 
However, the quality indicators are generic and can be adapted to "peculiarities and contexts of institutions and programmes" (The Commonwealth of Learning and National Assessment and Accreditation Council, 2017a). The authors further suggested that the indicators could be assessed on a five-point scale which could permit the calculation of weighted average in order to determine the overall performance of a programme or aspects of it. The five-point scale consists of:

$\begin{aligned} \text { i. } & \text { Needs Improvement - } 1 \\ \text { ii. } & \text { Can do Better - } 2 \\ \text { iii. } & \text { Satisfactory - } 3 \\ \text { iv. } & \text { Good - } 4 \\ \text { v. } & \text { Outstanding - } 5\end{aligned}$

\section{India}

Prasad (2005) extensively studied and was also involved in the accreditation of higher education in India. He provided the following generic framework of the higher education assessment and accreditation in India.

Table 6: Criteria for assessment and weightages in Indian higher education accreditation

\begin{tabular}{|l|l|c|c|c|}
\hline SN & Criteria & $\begin{array}{c}\text { University level } \\
\text { institutions }\end{array}$ & $\begin{array}{c}\text { Affiliated/ } \\
\text { Constituent } \\
\text { college }\end{array}$ & $\begin{array}{c}\text { Autonomous } \\
\text { college }\end{array}$ \\
\hline 1 & Curricular aspects & 15 & 10 & 15 \\
\hline 2 & $\begin{array}{l}\text { Teaching-learning and } \\
\text { evaluation }\end{array}$ & 25 & 40 & 30 \\
\hline 3 & $\begin{array}{l}\text { Research, consultancy } \\
\text { and extension }\end{array}$ & 15 & 05 & 10 \\
\hline 4 & $\begin{array}{l}\text { Infrastructure and } \\
\text { learning resources }\end{array}$ & 15 & 15 & 10 \\
\hline 5 & $\begin{array}{l}\text { Student Support and } \\
\text { progression }\end{array}$ & 10 & 10 & 10 \\
\hline 6 & $\begin{array}{l}\text { Organization and } \\
\text { management }\end{array}$ & 10 & 10 & 10 \\
\hline 7 & Healthy practices & 10 & 10 & \\
\hline
\end{tabular}

\section{SUGGESTIONS FOR NIGERIA}

Nigeria is one of the foremost African countries to embrace the professionalization of teaching. Therefore, it has multiple agencies that ensure the quality of teacher education. These agencies are the National Universities Commission (NUC) enacted into law in 1974 (Federal Republic of Nigeria, 1974) which has a generic framework for accrediting all degree programmes in Nigeria; National Commission for Colleges of Education (NCCE) set up by Acts No. 3 of 1989 and No. 12 of 1993 (Federal Republic of Nigeria, 1989/1993) and dedicated specifically to quality assurance of the Nigeria Certificate of Education (NCE) programmes run in the nation's colleges of education; and Teachers Registration Council of Nigeria (TRCN) established by the TRCN Decree No. 31 of 1993 which later became Act 2004 (Federal Republic of Nigeria $1993 / 2004$ ) and which is empowered to regulate and control the teaching profession in Nigeria at all levels and in all ramifications. By this provision, TRCN has powers to assure the quality of teacher education both in the universities and colleges of education.

However, a major deficiency of the accreditation system of teacher education in Nigeria is, unlike what obtains in the developed systems, the professional standards for teachers have not been the pivot of the quality indicators and process of the accreditation. The simple reason is 
that the professionalisation of teaching is recent and the development and implementation of the professional standards are also new. The standards were introduced in 2012 by the Teachers Registration Council of Nigeria and it is only slowly permeating and gaining ground in the regulation of teacher education and practice. For this reason, the quality indicators for the accreditation of teacher education have varied greatly among the three key agencies named above which are responsible for the accreditation of teacher education. In fact, at the degree level, there is no accreditation of teacher education from the professional angle - teacher education at the degree level is only accredited by the National Universities Commission using the same generic instruments and quality indicators for all degree programmes (NUC, 2017). At the Nigeria Certificate in Education level (a three-year post-secondary teacher education programme), the National Commission for Colleges of Education uses its own generic quality framework and indicators (NCCE, 2018). None of these explicitly takes cognisance of the professional standards for teachers.

Again, a further setback is the fact that the Teachers Registration Council of Nigeria has not at all commenced accreditation of any of the regular teacher education programmes in Nigeria the Nigeria Certificate in Education and Bachelor's degree in Education. None of these is currently being accredited by the Council though the law establishing it empowers it to accredit and ensure the quality of teacher education. The Council has only been accrediting the teacher education programmes that it developed to assist unqualified teachers and it uses accreditation instruments suited only for these programmes (TRCN, 2015, 2018). The programmes include the Professional Diploma in Education (PDE) and Post-Doctoral Diploma in Education (PDDE) run by some colleges of education and universities.

Based on these and other challenges, there is the need to fashion out national quality framework and indicators for the professional accreditation of teacher education programmes in Nigeria. Also, the accreditation instruments should have the professional standards as foundation and take cognisance of the international best practices in the accreditation of teacher education. Basically, this paper attempts to make contributions in this direction.

\section{The Nigerian professional standards}

For the professionalization of teaching in Nigeria, the TRCN (2012) issued the Professional Standards for Nigerian Teachers which is the basic benchmark for gauging teacher competences and quality in the country. The standards, as in the case of Australia, also have the novel feature of classifying teachers into categories. In the case of Nigeria, there are four categories based on the academic qualifications such as the NCE, Bachelor, Master and Doctorate degree teachers. For every standard, each of these categories has its expected competences clearly stated. There are eighty four (84) standards spread across four (4) themes and thirty six (36) sub-themes. The four themes are:

i. Professional knowledge,

ii. Professional skills,

iii. Professional values, attitude and conduct, and

iv. Professional membership obligations.

These thirty six (36) sub-themes are the areas of competences that should inform teacher education in Nigeria. Indeed, they are the quality framework that should guide the accreditation of teacher education in Nigeria while each of the 84 standards suggest the indicators. Teacher education institutions should provide evidences that their programmes had or can accomplish the professional standards. It is also important to note that the professional standards document has a a template with a 5-point rating scale (as appendix) 
which can facilitate the assessment of teachers to ascertain the extent they had met the 84 standards.

In line with international best practices, it is suggested that the Nigerian professional standards should be the foundation of the quality framework and indicators for the accreditation of all levels of teacher education. Fortunately, the professional standards have catered for all categories of teachers - Nigeria Certificate in Education, Bachelor, Master and Doctorate level teachers. The quality framework and indicators for accrediting any level of teacher education should target the competences stipulated for that level by the professional standards. Table 7 is a sketch of the four (4) themes and thirty six (36) sub-themes of the Nigerian professional standards.

Fig. 2: Relationship between the professional standards and quality framework and indicators for accreditation of teacher education

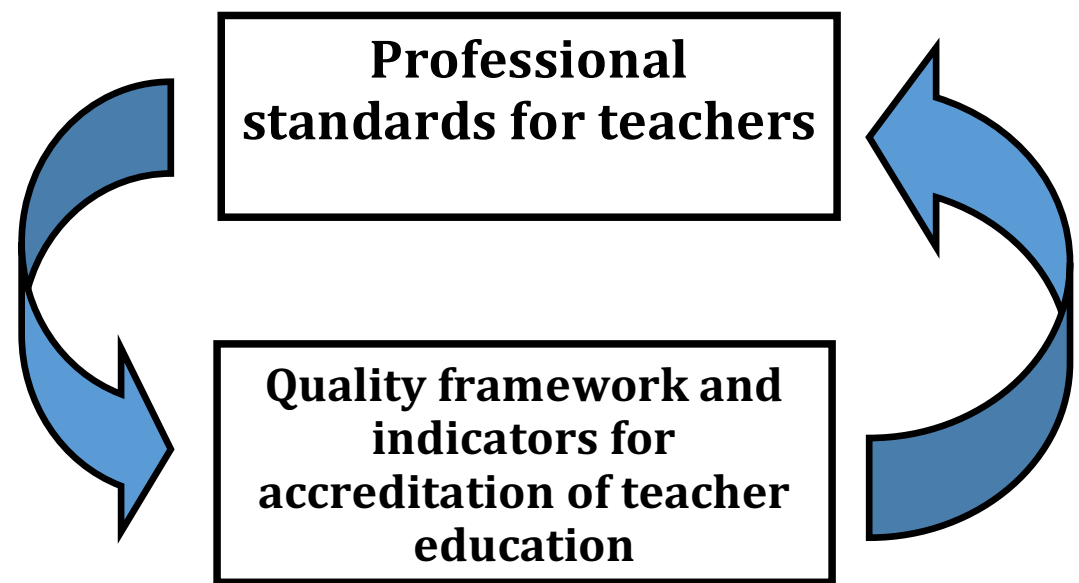


Table 7: Themes and sub-themes of the professional standards for Nigerian teachers and the rating scale

\begin{tabular}{|c|c|c|c|c|c|c|}
\hline \multirow[t]{2}{*}{ Themes } & \multirow[t]{2}{*}{ Sub-themes } & \multicolumn{5}{|c|}{ Rating } \\
\hline & & 1 & 2 & 3 & 4 & 5 \\
\hline \multirow{7}{*}{$\begin{array}{c}1 . \\
\text { Professional } \\
\text { Knowledge }\end{array}$} & 1.1 Subject content & & & & & \\
\hline & 1.2 Pedagogy & & & & & \\
\hline & 1.3 National Curriculum Requirements & & & & & \\
\hline & 1.4 Literacy and Numeracy & & & & & \\
\hline & 1.5 Information and Communications Technology & & & & & \\
\hline & 1.6 Students' socio-economic background & & & & & \\
\hline & 1.7 Students' Physio-Psychological Background & & & & & \\
\hline \multirow{10}{*}{$\begin{array}{c}2 . \\
\text { Professional } \\
\text { Skills }\end{array}$} & 2.1 Planning & & & & & \\
\hline & 2.2 Resourcefulness & & & & & \\
\hline & 2.3 Teaching \& Communication & & & & & \\
\hline & 2.4 Evaluation of Learners' Performance & & & & & \\
\hline & 2.5 Reporting & & & & & \\
\hline & 2.6 Record keeping & & & & & \\
\hline & 2.7 Programme Monitoring and Evaluation & & & & & \\
\hline & 2.8 Health, Safety and Human Rights & & & & & \\
\hline & 2.9 Learning Environment & & & & & \\
\hline & 2.10 Team Working and Collaboration & & & & & \\
\hline \multirow{7}{*}{$\begin{array}{c}3 . \\
\text { Professional } \\
\text { Values, } \\
\text { Attitude and } \\
\text { Conduct }\end{array}$} & 3.1 Relationship with learners & & & & & \\
\hline & 3.2 Relationship with Colleagues & & & & & \\
\hline & 3.3 Administrative and Academic Leadership & & & & & \\
\hline & 3.4 Relationship with Parents and Guardians & & & & & \\
\hline & 3.5 Relationship with Employers & & & & & \\
\hline & 3.6 Relationship with Society & & & & & \\
\hline & 3.7 General Relationship & & & & & \\
\hline \multirow{12}{*}{$\begin{array}{c}4 . \\
\text { Professional } \\
\text { Membership } \\
\text { Obligations }\end{array}$} & 4.1 Induction of Education Students at Point of Graduation & & & & & \\
\hline & 4.2 Registration with TRCN & & & & & \\
\hline & 4.3 Licensing & & & & & \\
\hline & 4.4 Internship & & & & & \\
\hline & 4.5 Continuous Professional Development & & & & & \\
\hline & 4.6 Professional Excellence & & & & & \\
\hline & 4.7 Professional Commitment & & & & & \\
\hline & 4.8 Efficiency & & & & & \\
\hline & 4.9 Precepts & & & & & \\
\hline & 4.10 Arbitration & & & & & \\
\hline & 4.11 Community Service & & & & & \\
\hline & 4.12 Education Laws & & & & & \\
\hline
\end{tabular}

Source: Extracts from TRCN (2012)

Similarly, the suggested generic quality framework and indicators for teacher education in Nigeria are presented in table 8 . The regulatory agencies can adapt these to the peculiarities and local contexts of the respective teacher education programmes. The primary aim of the quality framework is to ensure that teacher education programmes demonstrate their capacity to meet the professional standards for Nigerian teachers. 
Table 8: Suggested quality framework and indicators for accreditation of teacher education programmes in Nigeria

\begin{tabular}{|c|c|c|c|c|c|c|}
\hline \multirow[t]{2}{*}{ Standards } & \multirow[t]{2}{*}{ Few quality indicators for illustration } & \multicolumn{5}{|c|}{ Rating } \\
\hline & & 1 & 2 & 3 & 4 & 5 \\
\hline \multirow{14}{*}{$\begin{array}{c}1 . \\
\text { Programme } \\
\text { Organisation, } \\
\text { management } \\
\text { and } \\
\text { leadership }\end{array}$} & $\begin{array}{l}\text { 1.1 Evidence of institutional accreditation by the relevant national } \\
\text { agency }\end{array}$ & & & & & \\
\hline & 1.2 Institution's vision and mission & & & & & \\
\hline & $\begin{array}{l}\text { 1.3 Institution's statement of value and prioritisation of the } \\
\text { programme }\end{array}$ & & & & & \\
\hline & $\begin{array}{l}\text { 1.4 Degree of integration in institution's processes (calendar, } \\
\text { budgeting, academic board, etc.) }\end{array}$ & & & & & \\
\hline & 1.5 History of the institution's innovation and creativity & & & & & \\
\hline & $\begin{array}{l}\text { 1.6 Statement of institutional climate (considering participatory and } \\
\text { transparent leadership, staff-students relations, industrial harmony, } \\
\text { relations with host community, and other institutional and } \\
\text { environmental factors) }\end{array}$ & & & & & \\
\hline & 1.7 Qualifications of heads of the programme & & & & & \\
\hline & 1.8 Students admission procedure & & & & & \\
\hline & 1.9 Students entry qualifications & & & & & \\
\hline & 1.10 Diversity of students & & & & & \\
\hline & 1.11 Availability of guidance and counselling services for students & & & & & \\
\hline & 1.12 Management information system & & & & & \\
\hline & 1.13 Process of internal quality assurance/audit & & & & & \\
\hline & $\begin{array}{l}\text { 1.14 Fiscal policy of the programme - Funding sources, budget, } \\
\text { adequacy. }\end{array}$ & & & & & \\
\hline \multirow{13}{*}{$\begin{array}{c}2 . \\
\text { Curriculum } \\
\text { Interpretation } \\
\text { and } \\
\text { Availability }\end{array}$} & 2.1 Programme philosophy and vision & & & & & \\
\hline & 2.2 Curriculum integrity (agreement with the professional standards) & & & & & \\
\hline & 2.3 Curriculum adaptation (to local contexts) & & & & & \\
\hline & 2.4 Academic calendar & & & & & \\
\hline & 2.5 Scheme of work & & & & & \\
\hline & 2.6 Time tabling & & & & & \\
\hline & 2.7 Course content for students & & & & & \\
\hline & 2.8 Course outlines for students & & & & & \\
\hline & 2.9 Curriculum availability to students/student handbook & & & & & \\
\hline & 2.10 Reference lists for courses & & & & & \\
\hline & 2.11 Links to online resources & & & & & \\
\hline & 2.12 Clear statement of graduate outcomes & & & & & \\
\hline & $\begin{array}{l}\text { 2.13 Continual improvement of curriculum in line with emerging } \\
\text { national and global best practices and research outcomes. }\end{array}$ & & & & & \\
\hline \multirow{7}{*}{$\begin{array}{l}\text { 3. } \\
\text { Support for } \\
\text { Students }\end{array}$} & 3.1 Adequacy of orientation programmes for fresh students & & & & & \\
\hline & 3.2 Management of students with special needs & & & & & \\
\hline & 3.3 Completion/drop-out rate and remedial strategies & & & & & \\
\hline & 3.4 Students social participation and facilitation & & & & & \\
\hline & 3.5 Students motivation/satisfaction in the programme & & & & & \\
\hline & 3.6 Induction of students at point of graduation. & & & & & \\
\hline & 3.7 Procedure for dealing with students' complaints & & & & & \\
\hline \multirow{5}{*}{$\begin{array}{c}4 . \\
\text { Competences } \\
\text { and } \\
\text { Motivation of } \\
\text { Faculty }\end{array}$} & 4.1 Academic and professional qualifications of the faculty & & & & & \\
\hline & 4.2 Specialisation vis-a-viz assigned courses & & & & & \\
\hline & 4.3 Capacity of faculty as models and mentors & & & & & \\
\hline & $\begin{array}{l}\text { 4.4 Support and facilities to enable facilitators to execute their tasks } \\
\text { effectively }\end{array}$ & & & & & \\
\hline & 4.5 Faculty motivation/satisfaction in the programme & & & & & \\
\hline
\end{tabular}




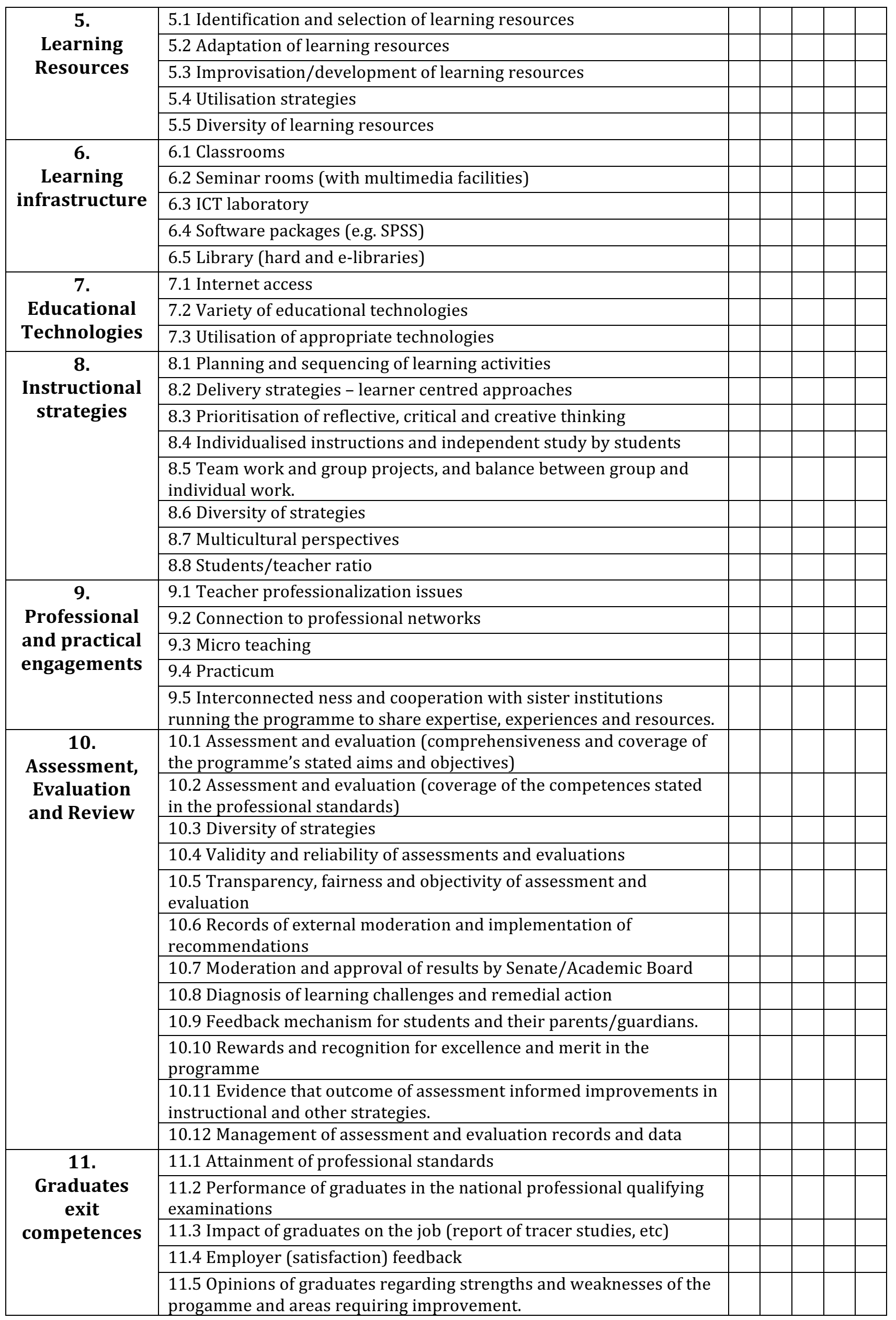




\begin{tabular}{|c|c|}
\hline \multirow{2}{*}{$\begin{array}{c}12 . \\
\text { Research and } \\
\text { Development }\end{array}$} & $\begin{array}{l}\text { 11.6 Evidences of on-going action research in general and specialised } \\
\text { education areas }\end{array}$ \\
\hline & $\begin{array}{l}11.7 \text { Evidences of integration of research outcomes in the programme } \\
\text { for improvement purposes. }\end{array}$ \\
\hline
\end{tabular}

In essence, an institution seeking accreditation for a new teacher education programme should provide convincing evidences that the graduates and programme will rate favourable on the professional standards scale and on the specific accreditation quality framework and indicators, respectively. Where an institution is seeking accreditation for a long-standing programme, it should provide convincing evidences that the graduates and operations of the programme had met the professional standards and quality indicators. In the later case, accreditation can only be obtained based on the amount of data and evidences accumulated over the years to convince the regulatory agencies that the programme had met the professional and accreditation quality framework.

\section{CONCLUSION}

The role of the teacher in the education system is a very critical one and how effectively the teacher plays the role depends on the effectiveness of teacher education. Both types of teacher education (initial teacher education and continuing professional development) form the continuum of lifelong learning required of a professional. Quality assurance in form of accreditation is necessary to ensure that both types of education meet the national professional standards for teaching. For this reason, the accreditation of teacher education occupies an important place in the discourse about the professionalisation of teaching and improvement in the quality of teaching and learning.

However, the scenario of accreditation has varied greatly across the continents of the world and even within countries. The advanced countries had taken the professionalisation of teaching seriously and subjected their teacher education programmes to effective accreditation. The developing countries, however, are still on the way to fully professionalise teaching and entrench the accreditation of teacher education. Even for a country like Nigeria, which is one of the foremost in the professionalisation of teaching in Africa, the regular teacher education programmes have not started to enjoy professional accreditation by the teaching regulatory authority. It therefore became important to review the international best practices and present a model of quality framework and indicators that Nigeria may adopt for the professional accreditation of teacher education programmes. This is essentially what this paper has done. It is hoped that the entire study and suggestions will generate healthy debate and offer significant insight into the best practices in the accreditation of teacher education and how best to contextualise them for Nigeria.

\section{References}

Australian Government (2000). Education services for overseas students (ESOS) Act. (https://www.studyinaustralia.gov.au/english/australian-education/education-system/esos-act)

Australian Government (2011). Tertiary Education Quality and Standards Agency Act No. 73, 2011. Federal Register of Legislation (https://www.legislation.gov.au/Details/C2015C00025)

Australian Institute for Teaching and School Leadership, AITSL (2011). National professional standards for teachers. Carlton South: Education Services Australia.

Australian Institute for Teaching and School Leadership, AITSL (2015a). Accreditation of initial teacher education programs in Australia: Standards and Procedures. Melbourne: AITSL.

Australian Institute for Teaching and School Leadership, AITSL (2015b). Primary specialisation: Graduate outcomes stimulus paper. Melbourne: AITSL. 
Australian Institute for Teaching and School Leadership, AITSL (2015c). Insights: Outcomes of the 2015 national initial teacher education accreditation panel review. Melbourne: AITSL.

Australian Institute for Teaching and School Leadership, AITSL (2016). Guidelines for the accreditation of initial teacher education progams in Australia. Melbourne: AITSL.

Australian Institute for Teaching and School Leadership, AITSL (2018). Guidelines for the accreditation of initial teacher education programs in Australia: Stage two. Melbourne: AITSL.

Australian Teacher Education Ministerial Advisory Group (2014). Best practice teacher education programs and Australia's own programs. Canberra: Australian Council for Educational Research.

(https://www.bcteacherregulation.ca/TeacherEducation/ProgramApproval.aspx)

Caena, F. (2011) Literature review teachers' core competences: requirements and development. Paper for the European Commission, Education and Training 2020 Thematic Working Group.

(ec.europa.eu/dgs/education.../education/...framework/doc/teacher-competences_en.pd...)

Caena, F. (2014). Initial teacher education in Europe: an overview of policy issue. Paper for the European Commission, Education and Training 2020 Working Group on Schools Policy.

(ec.europa.eu/.../education.../education/policy/...framework/...groups/.../initial-teacher-...)

Chalmers, D. (2007). A review of Australian and international quality systems and indicators of learning and teaching. Strawberry Hills NSW: Carrick Institute for Learning and Teaching in High Education Ltd.

Chalmers, D. (2008). Teaching and learning quality indicators in Australian universities. IMHE Programme on institutional management in higher education - Outcomes of higher education: Quality relevance and impact, Paris, France

Commission des titres d'ingénieur (CTI) (2017). Accreditation criteria, guidelines and procedures. (https://www.cti-commission.fr/.../2017/.../cti-references-guidelines-2018 web_20171...)

National Assessment and Accreditation Council \& Commonwealth of Learning (2006). Quality assurance in higher education: An introduction. Bangalore: NAAC.

National Assessment and Accreditation Council \& Commonwealth of Learning (2007a). Quality indicators for teacher education. Bangalore: NAAC.

National Assessment and Accreditation Council \& Commonwealth of Learning (2007b). An anthology of "best practices" in teacher education. Bangalore: NAAC.

Council for the Accreditation of Educator Preparation, CAEP (2016). CAEP accreditation handbook, 2018. Washington, DC: CAEP

Council for the Accreditation of Educator Preparation, CAEP (2018). CAEP handbook: Initial level programs, 2018. Washington, DC: CAEP

Council on Higher Education, South Africa (2004a). Framework for programme accreditation. Pretoria: CHE

Council on Higher Education, South Africa (2004b). Criteria for programme accreditation. Pretoria: CHE

Council on Higher Education, South Africa (2014). Accreditation revisited. CHE Quality Assurance Forum Professional Bodies, 11 March.

Eaton, J.S. (2016). Accreditation and recognition in the United States. Washington: Council for Higher Education Accreditation (CHEA).

Education Council, New Zealand (2016). Approval, review and monitoring processes and requirements for initial teacher education programmes. Wellington: EC.

Education Council, New Zealand (2018). Our code, our standards: Code of professional responsibility and standards for the teaching profession. Wellington: EC.

European Commission (2018). Proposal for a Council recommendation on Key Competences for lifelong Learning. (https://ec.europa.eu/education/sites/education/files/swd-recommendation-key-competences-lifelonglearning.pdf)

European Commission, Education and Culture (2010). Common European Principles forTeacher Competences and Qualifications. (www.pef.uni-lj.si/bologna/dokumenti/eu-common-principles.pdf)

Eurydice (2006). Quality assurance in teacher education in Europe. Brussels: Eurydice. With support of the European Commission, Directorate General for Education and Culture

Federal Republic of Nigeria (1974). National Universities Commission Act. Lagos: Government Printer. 
Federal Republic of Nigeria (1989/1993). National Commission for Colleges of Education Act No. 3 of 1989/Act No. 12 of 1993. Abuja: Government Printer.

Federal Republic of Nigeria (1993/2004). Teachers Registration Council of Nigeria Act 2004. Abuja: Government Printer.

General Teaching Council for Scotland (2012). Code of professionalism and conduct. Edinburgh: GTCS.

General Teaching Council for Scotland (2016). Policy statement: Accreditation of programmes of initial teacher education in Scotland. Edinburgh: GTSC.

General Teaching Council for Scotland (2018). Evaluation framework: Accreditation of programmes of initial teacher education in Scotland. Edinburgh: GTCS.

International Task Force on Teachers for Education 2030 (2017). Outcome statement of the $10^{\text {th }}$ Policy Dialogue Forum held in Lome, Togo, September 18-21.

National Assessment and Accreditation Council of India \& Commonwealth of Learning (2007a). Quality assurance in higher education: An introduction. Bangalore: NNAC.

National Assessment and Accreditation Council of India \& Commonwealth of Learning (2007b). Quality indicators for teacher education. Bangalore: NAAC.

National Council for Accreditation of Teacher Education, USA (2008). Professional standards for the accreditation of teacher preparation institutions. Washington, DC: NCATE

Ontario, Canada (1996). Ontario College of Teachers Act, 1996, S.O. 1996, c. 12.

Ontario College of Teachers (1996). Reg. 347/02: Accreditation of teacher education programmes. Toronto: OCT. Ontario College of Teachers (2015). Looking at... Enhanced teacher education. Toronto: OCT.

Ontario College of Teachers (2016). Additional qualifications: Extending professional knowledge. Toronto: OCT.

Ontario College of Teachers (2017a). The professional learning framework. (https://www.oct.ca/public/professional-standards/professional-learning-framework)

Ontario College of Teachers (2017b). Accreditation resource guide. Toronto: OCT. Ontario College of Teachers (2018). Standards of practice for the teaching profession and ethical standards for the teaching profession. Toronto: OCT.

Prasad. V.S. (2005). Accreditation of HEIs in India: The NAAC Experience. Paper presented by the Director National Assessment and Accreditation Council (NAAC), Bangalore, India.

(www.che.ac.za/sites/default/files/.../d000091_seminar_9-3-05-Int-trends-qa-prasad.pd...)

Sanyal, B.C. (2013). Quality assurance of teacher education in Africa. Addis Ababa: UNESCO-IICBA.

Sywelem, M.M..G (2014). Accreditation models in teacher education: The cases of United States, Australia and India. International Journal of Education and Research, 2(3):1-12.

Teacher Education Accreditation Council, USA (2012). Guide to accreditation. Newark: TEAC.

Teachers Registration Council of Nigeria (2018). Accreditation guidelines for all schools running Professional Diploma in Education. Abuja: TRCN.

Teachers Registration Council of Nigeria (2012). Professional standards for Nigerian teachers. Abuja: TRCN.

General Teaching Council for Scotland (1965). Teaching Council (Scotland) Act of 1965. London: Her Majesty's Stationery Office.

World Bank Group (2009). Teacher education quality assurance: Accreditation of teacher education institutions and programs: Policy Brief. (siteresources.worldbank.org/INTSOUTHASIA/Resources/PolicyBrief2.pdf) 